\title{
Kualitas Air Dan Invertebrata Tanah: Sebuah Review
}

\author{
Syifa Saputra \\ Program Studi Pendidikan Biologi, FKIP Universitas Almuslim Bireuen, Aceh \\ Email: syifa.mpbiounsyiah@gmail.com
}

\section{Pendahuluan}

Tulisan ini meriview tentang pencemaran air yang berdampak pada kualitas air. Tingkat pencemaran air di kota-kota besar yang dikonsumsi oleh manusia terkontaminasi baik yang dikonsumsi secara lansung maupun tidak lansung. Berbagai polutan misalnya seperti emisi asap kenderaan bermotor, emisi dari pabrik-pabrik industri, partikel aus ban, pertikel jalan beraspal yang rusak, bengkel-bengkel, pabrik kimia dan lain-lain menjadi faktor penyebab terhadap resiko kesehatan. Selain dari polutan tersebut, sumber-sumber lain juga bisa berasal dari pertambangan, pembuangan limbah, pestisida, aplikasi pupuk dan sebagainya. Hal ini pernah dikaji di china, bahwa di china sudah terkontaminasi polutan yang tidak lagi terjaga kualitas kesehatan lingkungan, disebabkan oleh pembangunan industrialisasi yang tumbuh secara cepat. Sementara air, tanah, udara dan tanaman tecemar oleh logam berat bahkan setelah diteliti berdampak pada kesehatan manusia melalui asupan lansung.

Pencemaran logam berat telah terjadi di berbagai belahan dunia hal ini tercermin dari masuknya berbagai polutan mapun berbagai aktivitas pertambangan di cina, akibat dari pencemaran logam berat berdampak pada kesehatan manusia. Cina memiliki sumber daya mineral yang beragam yang terdiri dari 171 jenis sumber daya mieral. Disamping itu cina juga termasuk salah satu produsen terbesar seperti antimon ( $\mathrm{Sb}$ ), Besi (Fe), Timbal $(\mathrm{Pb})$, Mangan $(\mathrm{Mn})$, Timah ( $\mathrm{Sn})$, Tungsten $(\mathrm{W})$ danseng ( $\mathrm{Zn})$ begitu juga dengan batu bara. Oleh karena itu dalam penggunan sumber daya mineral sebagai kunci utama dalam pembangunan social - ekonomi (Li, Ma, van der Kuijp, Yuan, \& Huang, 2014).

Selain pencemaran dari logam berat, plastik juga menjadi pemicu pencemaran lingkungan termasuk salah satunya adalah pencemaran untuk komunitas aquatik. Tanah adalah sumber daya yang paling berharga bagi kehidupan manusia. Makanan yang kita 
makan hingga pakaian yang kita kenakan tidak dapat dipisahkan oleh nasib tanah kita. Meningkatnya aktivitas manusia terhadap lingkungan mengakibatkan degradasi ekosistem secara luas. Berbagai upaya dilakukan untuk mengembalikan lingkungan darat dan air diantaranya struktur vegetasi, keanekaragaman spesies serta siklus nutrisi. Upaya rehabilitasi mengunakan indicator biologis, karena dapat memantau dan menilai keadaan suatu ekosistem. Sehingga keanekaragaman hayati invertebrata soil dapat menjadi bioindikator lingkungan.

Lingkungan memiliki kemampuan bertahan dalam keadaan dan menetralkan diri kembali ke keadaan awal jika limbah tersebut masih berada dalam batas daya dukung lingkungan tersebut. khusus untuk mikroorganisme, jenis dan jumlahnya di lingkungan dipengaruhi oleh karakteristik lingkungan dan limbah yang masuk kelingkungan yang dapat menghambat dan menstimulus pertumbuhan mikroorganisme.

Produksi dan penggunaan plastic terus meningkat seiring dengan kebutuhan manusia dan bahkan produksi plastik mencapai 300 juta ton/tahun. Dengan demikian penggunaan plastic telah meningkat dari waktu ke waktu karena mikroplastik yang dihasilkan dapat menimbulkan resiko lingkungan aquatic, akibat dari pembuangan sembarangan dan cenderung untuk tidak mudah dicerna oleh hewan maupun tidak mudah di uraikan oleh mikroba (Anderson, Park, \& Palace, 2016).

Kegunaan Invertebrata sebagai bioindikator:

- Lingkungan fisik yang berubah (suhu, jenis substrat, kedalaman, instensitas cahaya, dan lain-lain)

- Lingkungan kimia yang berubah $(\mathrm{pH}$, Konsentrasi Logam Berat, Faktor Nutrien dan lain-lain)

- Kualitas komparatif atau Nilai Konservasi Habitat (tidak Ada spesies langka, lokal atau terancam punah)

- Perubahan status habitat ekologis (terjadi secara alami/dampak manusia)

Invertebrata adalah organisme yang pola distribusinya berlimpah di bumi karena memiliki mekanisme penyebaran aktif dan pasif yang jika habitat terganggu maka 
dengan cepat terjadi kolonisasi kembali. Dampak dari pencemaran air dan tanah akibat dari berbagai polutan akan mengakibatkan pada tergangunya rantai makanan, menurunnya kadar osigen baik dalam air maupun tanah, sehingga dari pencemaran ini akan menyebabkan beberapa hewan air dan tanah akan mati kekurangan oksigen

Pemanfaatan invertebrata terhadap gangguan lingkungan

- Invertebrata merupakan indikator yang berpotensi untuk memantau keberhasilan rehabilitasi

- Tidak semua invertebrata baik digunakan sebagai bioindikator lingkungan

- Setiap jenis invertebrata yang dinilai mampu memberikan perilaku spesialis, sensitive terhadap perubahan habitat dan distribusi yang luas

\section{Hasil yang didapatkan}

Hasil penelitian menunjukkan $\mathrm{Cr}, \mathrm{Ni}, \mathrm{Cu}, \mathrm{Pb}, \mathrm{Zn}, \mathrm{As}, \mathrm{Hg}$ dan $\mathrm{Cd}$ lebih tinggi tingkat kontaminasinya jika dibandingkan dengan kondisi tanah dasar di cina. Dari indeks geokumulasi menunjukkan bahwa kontaminasi $\mathrm{Cr}, \mathrm{Ni}, \mathrm{Cu}, \mathrm{Pb}, \mathrm{Zn}$ dan $\mathrm{Cd}$ tersebar di daerah tanah perkotaan (Wei \& Yang, 2010). Berbagai macam sumber mineral yang digunakan tidak hanya menurunkan kualitas atmosfer, badan air, tanaman pangan tetapi juga mengancam kesehatan dan kesejateraan hewan dan manusia melalui rantai makanan. Sebagai contoh $\mathrm{Pb}$ adalah elemen non esensial untk tubuh manusia jika dilakukan asupan yang berlebihan akan berdampak pada rusaknya sistem saraf, skeletal, sirkulasi, enzimatik, endokrin dan kekebalan tubuh akan menurun, selain itu paparan Cd juga dapat memiliki efek samping seperti kanker paru, adenokarsino paru, lesi proliferative prostat, fraktur tulang, disfungsi ginjal dan hipertensi, sedangkan efek dari As salah satunya terjadinya kanker kulit dan perifer penyakit vascular.

Oleh karena itu, meskipun logam berat dapat terjadi secara alami di tanah, tetapi konstribusi tambahan berasal dari aktivitas antropogenik seperti pertanian, urbanisasi, insdustrialisasi dan penambangan. Banyak penelitian menjelaskan bahwa polusi logam berat berasal dari aktivitas-aktivitas antropogenik.

Analisis dampak terhadap inventebrata tanah: 
- Masuknya antropogenik dari berbagai sumber pollutan juga akan berdampak pada invertebrate soil :

- Semutsebagai bioindicator : memiliki pola sebaran yang luas, melimpah, sebagai kunci utama dalam merespon keadaan lingkungan yang rusak

- Misalnya jenis tanah dapat memberikan efek terhadap perkumpulan semut di suatu area

- Arthropoda jenis hewan yang peka terhadap perubahan kondisi lingkungan dan juga bias digunakan sebagai indikator pencemaran tanah

- Athropoda tanah bertindak sebagai "variable pengendara" secara tidak lansung mempengaruhi jalur transfer energi

- Mikroba, bakteri, jamur, fauna makro (cacing tanah, kumbang, lipan, rayap dan lain-lain) dan akar tanaman dapat dianggap sebagai organisme dalam interaksi simbiotik

- Aktivitas fauna makro seperti cacing dan rayap mempengaruhi struktur tanah melalui percampuran bahan organic yang terkait dengan erosi dan ketersediaan unsur hara bagi tanaman.

- Hilangnya keanekaragaman hayati dan perubahan jasa ekosistem berdampak pada :

- Perubahan habitat : perubahan penggunaan lahan, perubahan iklim, masuknya spesies invasive, eksploitasi berlebihan dan polusi

- Semutdan athropoda lainnya bagian spesies bioindicator yang berharga dari keberhasilan restorasi lingkungan

\section{Simpulan}

- Pencemaran tanah oleh logam berat menimbulkan risiko tinggi kepada masyarakat, terutama untuk anak-anak 
- Sumber-sumber logam berat yang memiliki tingkat kontaminasi tinggi berasal dari aktivitas antropogenik.

- Akibat dari pencemaran logam berat, dapat menurunkan kualitas atmosfer, air, tanaman, mengancam kesehatan dan kesejahteraan hewan dan manusia melalui rantai makanan

- Tanah yang sehat adalah tanah kaya akan organisme mikroskopis yang berfungsi untuk mengubah materi yang mati menjadi tanah yang kaya akan nutrisi

- Aktivitas indicator biologis tergantung pada bahan organic yang masuk sehingga penting untuk kesuburan tanah, struktur tanah, siklus nutrisi dan keseimbangan agroekosistem.

\section{DaftarPustaka.}

Anderson, J. C., Park, B. J., \& Palace, V. P. (2016). Microplastics In Aquatic Environments: Implications For Canadian Ecosystems. Environmental Pollution, 218, 269-280. https://doi.org/10.1016/j.envpol.2016.06.074

Li, Z., Ma, Z., van der Kuijp, T. J., Yuan, Z., \& Huang, L. (2014). A Review Of Soil Heavy Metal Pollution From Mines In China: Pollution And Health Risk Assessment. Science of the Total Environment, 468-469, 843-853. https://doi.org/10.1016/j.scitotenv.2013.08.090

Wei, B., \& Yang, L. (2010). Review Article: A Review Of Heavy Metal Contaminations In Urban Soils, Urban Road Dusts And Agricultural Soils From China. Microchemical Journal, 94(2), 99-107. https://doi.org/10.1016/j.microc.2009.09.014 